\title{
Assessment of heavy metal concentration in edible fish muscle and water sample collected from different location in Chittagong: a public health concern
}

\author{
Jakia Sultana Jothi ${ }^{1,3}$, Ishrat Zahan Anka ${ }^{1}$, \\ Shaharior Hashem ${ }^{2,3}$, Shamsul Morshed ${ }^{1}$ \\ 1 - Chittagong Veterinary and Animal Sciences University, Bangladesh \\ 2 - Bangladesh Agricultural University, Bangladesh \\ 3 - Hiroshima University, Japan
}

Keywords:

Heavy metal

Water

Sea

Marine fish

Chittagong

Article history:

Received

19.07.2018

Received in

revised form

21.09.2018

Accepted

28.09.2018

Corresponding

author:

Jakia Sultana Jothi

E-mail:

juthi.engg.bau@

gmail.com

DOI:

10.24263/2304-

974X-2018-7-3-11

\section{Abstract}

Introduction. The research was carried out to investigate the concentration of heavy metals in fish and water samples collected from different locations of Chittagong District, Bangladesh.

Materials and methods. The concentrations of heavy metals including $\mathrm{Cr}, \mathrm{Cu}, \mathrm{Ni}, \mathrm{Pb}$ and $\mathrm{Fe}$ in sea water and marine fishes (pama croaker, bombay duck and rat-tail anchovy) were detected by using Air / Acetylene Flame Atomic Absorption Spectrophotometer along Chittagong City areas, Bangladesh.

Results and discussion. The mean concentration of heavy metals were found in water in the range as $\mathrm{Cr} 0.0138-0.0789$ $\mathrm{mg} / \mathrm{L}, \mathrm{Cu} 0.0014-0.0284 \mathrm{mg} / \mathrm{L}$, Ni 0.0259-0.2519 mg/L, Pb $0.0109-0.1596 \mathrm{mg} / \mathrm{L}$ and $\mathrm{Fe} 0.2176-1.787 \mathrm{mg} / \mathrm{L}$. The analysis of water samples showed that the distribution of heavy metals in the order of magnitude as $\mathrm{Fe}>\mathrm{Ni}>\mathrm{Pb}>\mathrm{Cr}>\mathrm{Cu}$. The variation might be due to location, level of contamination in water through industrial effluents and anthropogenic activities. While the mean concentration of heavy metals were found in all fish samples in the range as $\mathrm{Cr} 3.2039-16.3495 \mathrm{mg} / \mathrm{Kg}$ dry wt., $\mathrm{Cu} 1.5589-4.5848 \mathrm{mg} / \mathrm{Kg}$ dry wt., Ni $0.1101-1.9029 \mathrm{mg} / \mathrm{Kg}$ dry wt., $\mathrm{Pb} 0.4373-2.7638 \mathrm{mg} / \mathrm{Kg}$ dry wt. and $\mathrm{Fe} 30.9599-$ $108.780 \mathrm{mg} / \mathrm{Kg}$ dry wt. The distribution of heavy metals in fish samples analyzed were in the order of magnitude as $\mathrm{Fe}>\mathrm{Cr}>$ $\mathrm{Cu}>\mathrm{Pb}>\mathrm{Ni}$. The analysis showed that magnitudes of heavy metal were more or less similar with other researchers. The variation might be due to metal accumulation in fish and various fish species living in the same water body but different level of contamination in water. Among all samples, $17 \%$ fish samples had excess amount of $\mathrm{Cr}$ whereas acceptable limit is $15.0 \mathrm{mg} / \mathrm{kg}$ for fish. Mean concentrations of $\mathrm{Pb}$ in all fish samples were $17 \%$ below detection level, $33 \%$ optimum and $33 \%$ higher than the maximum permitted concentrations $(1.5$ $\mathrm{mg} / \mathrm{Kg}$ ). Fe in all fish samples were 33\% below, 17\% optimum and $50 \%$ higher than the maximum permitted concentrations (43 $\mathrm{mg} / \mathrm{Kg}$ ) recommended by $\mathrm{FAO} / \mathrm{WHO}$.

Conclusions. Most of the fish species studied are safe to be consumed. Therefore, this study is proposed to draw the attention of health and environmental authorities in need for appropriate regulatory framework. 


\section{Introduction}

Fish, as human food, are considered as a good source of protein, polyunsaturated fatty acids (particularly omega-3 fatty acids), calcium, zinc (Zn), and iron [1]. Due to the lower cost and higher nutritive value, it is one of the most important sources among the food products of animal origin [2,3]. In future, seafood will be an vital source of food protein and the safety for human consumption of products from aquaculture is of public health interest [4].

Heavy metals are an important source of food contamination and health hazard. The main threats to human health are associated with exposure to arsenic, cadmium, lead and mercury and copper. Absorption of heavy metals through food has been shown to have serious consequences on health- such as kidney disease, damage to the nervous system, diminished intellectual capacity, heart disease, gastrointestinal diseases, bone fracture, cancer and death [5].

Heavy metals are contaminants in the aquatic environment as well as became toxic health threat for human. Fish play important role in condensing the toxicity of heavy metals which have a great ecological significance due to their cumulative behavior and toxicity [3].

The most anthropogenic sources of metals are industrial, petroleum contamination and sewage disposal $[6,7]$. The aim of this study was to assess the levels of some heavy metals in water and fish specimens caught from different localities in Chittagong coastal area, Bangladesh. Public health importance and the hazardous toxic effects of these heavy metals and fish contamination with these were discussed.

\section{Materials and methods}

\section{Collection of water samples}

The water samples were obtained from 12 sampling stations established along 5 regions (Figure 1). The sampling stations were chosen based on an experimental scheme design following human activities in the area. These regions are main fishing centers of Chittagong, Bangladesh and also, a variety of industries and touristic centers are concentrated in these regions. Following the large volume of population and industries located there, the five regions were selected to measure the heavy metals concentrations in water samples during summer season (Table 1).

Table 1

List of sampling stations for water collection from Chittagong, Bangladesh

\begin{tabular}{|c|c|}
\hline Sampling station Code & Regions \\
\hline $\mathrm{W}_{1}$ & \multirow{2}{*}{ Majhir Ghat } \\
\hline $\mathrm{W}_{2}$ & \\
\hline $\mathrm{W}_{3}$ & \multirow{2}{*}{ Firingi Bazar } \\
\hline $\mathrm{W}_{4}$ & \\
\hline $\mathrm{W}_{5}$ & \multirow{2}{*}{ Sea-resource Ghat } \\
\hline $\mathrm{W}_{6}$ & \\
\hline $\mathrm{W}_{7}$ & \multirow{2}{*}{ Chaktai Khal } \\
\hline $\mathrm{W}_{8}$ & \\
\hline $\mathrm{W}_{9}$ & \multirow{2}{*}{ Uttar Kattoli } \\
\hline $\mathrm{W}_{10}$ & \\
\hline $\mathrm{W}_{11}$ & \multirow{2}{*}{ Uttar Kattoli Pond } \\
\hline $\mathrm{W}_{12}$ & \\
\hline
\end{tabular}




\section{Collection of fish specimens}

Pama croaker (Otolithoides pama), bombay duck (Harpadon nehereus) and rat-tail anchovy (Coilia ramcarati) were collected from four different market in Chittagong Metropolitan area, Bangladesh (Table 2). Twenty fish of each species were collected from each market. The fish were washed with deionized water and wrapped separately in acid washed polyethylene bags and were stored frozen at $-20^{\circ} \mathrm{C}$ until analysis.

\section{Materials}

All reagents used in this work $\left(\mathrm{HNO}_{3}, \mathrm{NaOH}, \mathrm{HCl}, \mathrm{KI}, \mathrm{HClO}_{4}, \mathrm{~K}_{2} \mathrm{CrO}_{4}, \mathrm{NaBH}_{4}\right.$, acetylene and argon gas) were of analytical grade and purchased from Merck (Germany).

List of market for fish collection in Chittagong, Bangladesh

Table 2

\begin{tabular}{|c|c|c|c|}
\hline \multirow{2}{*}{ Location } & \multicolumn{3}{|c|}{ Fish Samples code } \\
\cline { 2 - 4 } & Pama croaker & Bombay duck & Rat-tail anchovy \\
\hline Market 1 & $\mathrm{P}_{1}$ & $\mathrm{~B}_{1}$ & $\mathrm{R}_{1}$ \\
\hline Market 2 & $\mathrm{P}_{2}$ & $\mathrm{~B}_{2}$ & $\mathrm{R}_{2}$ \\
\hline Market 3 & $\mathrm{P}_{3}$ & $\mathrm{~B}_{3}$ & $\mathrm{R}_{3}$ \\
\hline Market 4 & $\mathrm{P}_{4}$ & $\mathrm{~B}_{4}$ & $\mathrm{R}_{4}$ \\
\hline
\end{tabular}

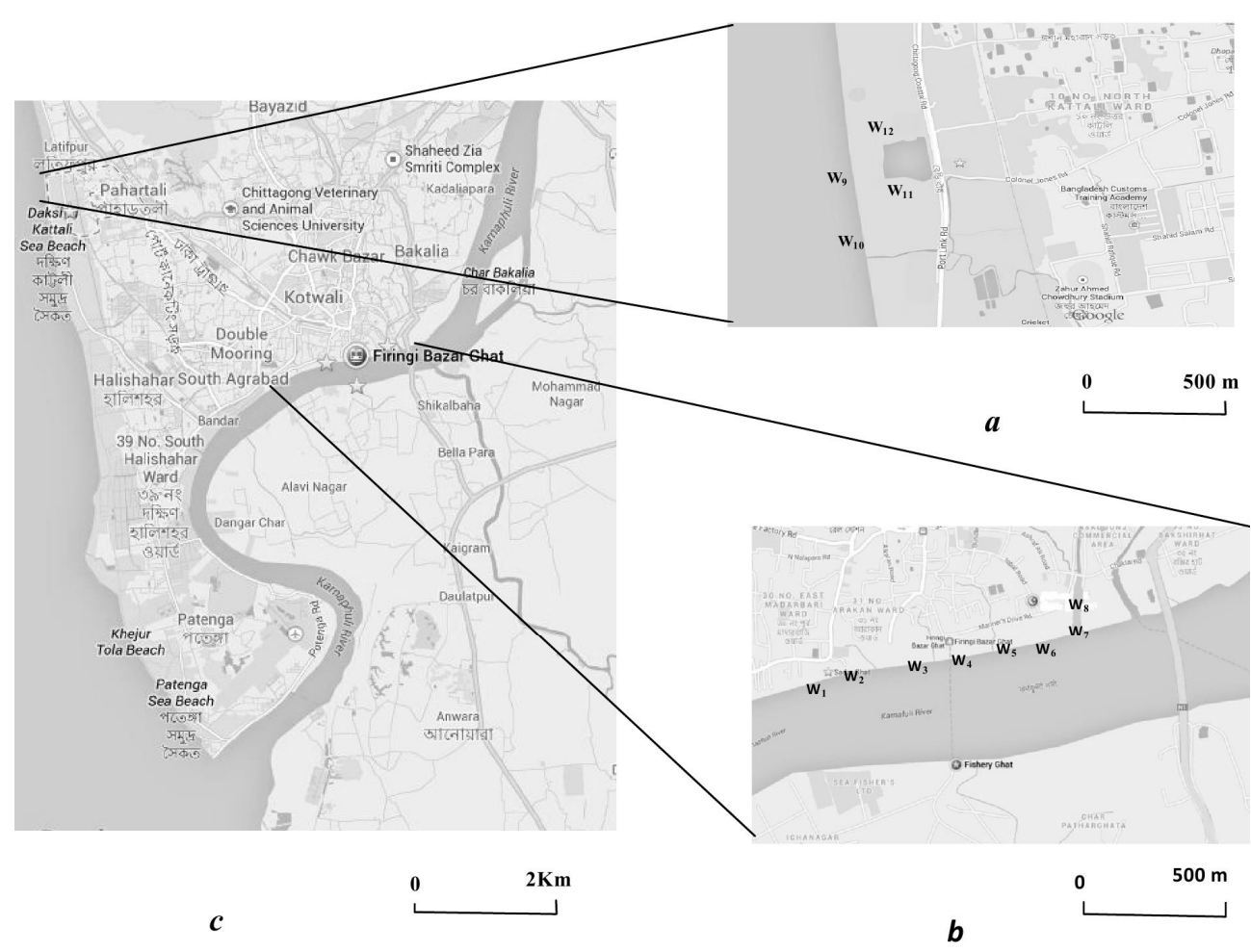

Figure 1. Location map of the study areas (Source: Google map, 2018) 


\section{Preparation and analysis of water samples}

The water samples were preserved by the addition of $1 \mathrm{ml}$ of concentrated nitric acid per liter until the time of analysis. The analysis of water samples was carried out according to American Public Health Association [8]. They were filtered through $0.45 \mu$ membrane filter. The required volume $(100 \mathrm{ml})$ of the filtrate was used to measure heavy metal levels in water samples by using Air/ Acetylene Flame Atomic Absorption Spectrophotometer.

\section{Preparation and analysis of fish specimens}

Fish samples were allowed for thawing and the skin of the fish was removed using a plastic knife to avoid metal contamination. The muscles of fish were taken into pre-acid washed crucibles and they were homogenized separately. The weight of each homogenized sample was recorded. Then the samples were kept in a drying oven at $100^{\circ} \mathrm{C}$ for more than $24 \mathrm{hrs}$ until a constant weight was observed. The dried samples were then ground into a fine powder using a porcelain motor and a pestle. Powdered fish tissues were digested using a dry ashing procedure [9]. They were filtered through $0.45 \mu$ membrane filter. The required volume $(100 \mathrm{ml})$ of the filtrate was used to measure heavy metal levels in water samples by using Air/ Acetylene Flame Atomic Absorption Spectrophotometer.

At each step of digestion processes, acid blanks were prepared in order to ensure that the samples and chemicals used were not contaminated. They were analyzed by atomic absorption spectrophotometer. Each set of digestion has its own acid blank and was corrected by using its blank.

Each standard solution was measured 3 times and the mean were plotted. A blank solution of distilled water was used to check accuracy of the standard solutions and it was run after every 10 samples.

The metal content will be calculated using the formula:

$$
C=\frac{C_{A A S} \cdot V}{W}
$$

where $\mathrm{C}$ - concentration (mg Kg ${ }^{-1}$ or ppm dry wt.)

$\mathrm{C}_{\mathrm{AAS}}-$ concentration of the element through AAS (ppm)

$\mathrm{V}$ - volume made up

\section{Data Analysis}

The data obtained from the experiments were statistically analyzed for find out mean and standard deviation among the various samples in triplicate. Data were analyzed using the software, IBM SPSS Statistics, version 20 at the 0.05 level.

\section{Results and dscussion}

\section{Heavy metal in sea water}

The Mean concentrations and associated standard deviations of $\mathrm{Cr}, \mathrm{Cu}, \mathrm{Ni}, \mathrm{Pb}$ and $\mathrm{Fe}$ in sea water are presented in Table 3. The mean concentration of heavy metals were found in water in the range as $\mathrm{Cr} 0.0138-0.0789 \mathrm{mg} / \mathrm{L}, \mathrm{Cu} 0.0014-0.0284 \mathrm{mg} / \mathrm{L}, \mathrm{Ni} 0.0259$ $0.2519 \mathrm{mg} / \mathrm{L}, \mathrm{Pb} 0.0109-0.1596 \mathrm{mg} / \mathrm{L}$ and $\mathrm{Fe} 0.2176-1.787 \mathrm{mg} / \mathrm{L}$. The distribution of heavy metals in water samples analyzed were in the order of magnitude as $\mathrm{Fe}>\mathrm{Ni}>\mathrm{Pb}>$ 
$\mathrm{Cr}>\mathrm{Cu}$. Ismail and Saleh (2012) [10] detected heavy metals of water in the order of Fe > $\mathrm{Cu}$, whereas concentrations $\mathrm{Pb}$ was below the detection limit. According to El-Kattan (2018) [3], the contents of heavy metals in water were in the order of degree as $\mathrm{Cr}>\mathrm{Cu}>$ $\mathrm{Pb}>$ Fe. Kumar et al. (2013) [12] also found heavy metal concentrations in Ennore creek sea water decreased in the order of $\mathrm{Cu}>\mathrm{Cr}>\mathrm{Ni}>\mathrm{Pb}$. The analysis showed that magnitudes of heavy metal were more or less similar with Ismail and Saleh (2012) [10] reported but differ from Ambedkar and Muniyan (2012) [11] and Kumar et al. (2013) [12]. The variation might be due to location, level of contamination in water through industrial effluents and anthropogenic activities.

Table 3

Concentration of heavy metal in sea water*

\begin{tabular}{|c|c|c|c|c|c|}
\hline $\begin{array}{c}\text { Sampling } \\
\text { station } \\
\text { Code }\end{array}$ & $\mathbf{C r}(\mathbf{m g} / \mathbf{l})$ & $\mathbf{C u}(\mathbf{m g} / \mathbf{l})$ & $\mathbf{N i}(\mathbf{m g} / \mathbf{l})$ & $\mathbf{P b}(\mathbf{m g} / \mathbf{l})$ & $\mathbf{F e}(\mathbf{m g} / \mathbf{l})$ \\
\hline $\mathrm{W}_{1}$ & $0.0530 \pm 0.0034$ & $0.0251 \pm 0.0038$ & $0.0259 \pm 0.0091$ & $0.1555 \pm 0.0130$ & $1.140 \pm 0.0340$ \\
\hline $\mathrm{W}_{2}$ & $0.0252 \pm 0.0234$ & $0.0188 \pm 0.0053$ & $0.0384 \pm 0.0017$ & $0.1596 \pm 0.0204$ & $1.270 \pm 0.0586$ \\
\hline $\mathrm{W}_{3}$ & $0.0303 \pm 0.0244$ & $0.0163 \pm 0.0039$ & $0.2350 \pm 0.0064$ & $0.0118 \pm 0.0013$ & $1.196 \pm 0.0387$ \\
\hline $\mathrm{W}_{4}$ & $0.0138 \pm 0.0123$ & $0.0284 \pm 0.0060$ & $0.2519 \pm 0.0035$ & $0.0109 \pm 0.0054$ & $1.280 \pm 0.0206$ \\
\hline $\mathrm{W}_{5}$ & $0.0518 \pm 0.0173$ & $0.0119 \pm 0.0070$ & $0.0568 \pm 0.0039$ & $0.1379 \pm 0.0141$ & $1.252 \pm 0.0179$ \\
\hline $\mathrm{W}_{6}$ & $0.0789 \pm 0.0197$ & $0.0081 \pm 0.0057$ & $0.0815 \pm 0.0026$ & $0.1313 \pm 0.0241$ & $1.342 \pm 0.0431$ \\
\hline $\mathrm{W}_{7}$ & $0.0310 \pm 0.0060$ & $0.0183 \pm 0.0034$ & $0.2007 \pm 0.0007$ & $0.0265 \pm 0.0039$ & $1.787 \pm 0.0088$ \\
\hline $\mathrm{W}_{8}$ & $0.0168 \pm 0.0058$ & $0.0259 \pm 0.0021$ & $0.2024 \pm 0.0026$ & $0.0129 \pm 0.0060$ & $1.325 \pm 0.0063$ \\
\hline $\mathrm{W}_{9}$ & $0.0237 \pm 0.0096$ & $0.0035 \pm 0.0019$ & $0.1179 \pm 0.0049$ & $0.1196 \pm 0.0117$ & $0.3382 \pm 0.0150$ \\
\hline $\mathrm{W}_{10}$ & $0.0304 \pm 0.0230$ & $0.0036 \pm 0.0013$ & $0.1348 \pm 0.0044$ & $0.1033 \pm 0.0190$ & $0.2848 \pm 0.0084$ \\
\hline $\mathrm{W}_{11}$ & $\mathrm{BDL}$ & $0.0014 \pm 0.0001$ & $0.1770 \pm 0.0037$ & $0.0976 \pm 0.0049$ & $0.3475 \pm 0.0303$ \\
\hline $\mathrm{W}_{12}$ & $\mathrm{BDL}$ & BDL & $0.1998 \pm 0.0024$ & $0.0662 \pm 0.0336$ & $0.2176 \pm 0.0106$ \\
\hline
\end{tabular}

* Values are mean \pm standard deviation of triplet determinations; BDL=Below Detection Level

The highest concentration level of $\mathrm{Cr}$ was found in $\mathrm{W}_{6}(0.0789 \mathrm{mg} / \mathrm{L})$, while the least concentration was detected in $\mathrm{W}_{4}(0.0138 \mathrm{mg} / \mathrm{L})$. But $\mathrm{Cr}$ was found below the detection level in pond water. $\mathrm{Cu}$ content in $\mathrm{W}_{4}(0.0284 \mathrm{mg} / \mathrm{L})$ was higher followed by lowest in $\mathrm{W}_{11}$ $(0.0014 \mathrm{mg} / \mathrm{L})$. In pond water sample $\left(\mathrm{W}_{12}\right) \mathrm{Cu}$ was analyzed below the detection limit. The highest Ni content was found $0.2519 \mathrm{mg} / \mathrm{L}$ in sample $\mathrm{W}_{4}$ and lowest value $0.0259 \mathrm{mg} / \mathrm{L}$ for sample $\mathrm{W}_{1}$. The maximum concentration of $\mathrm{Pd}$ was observed in $\mathrm{W}_{2}(0.1596 \mathrm{mg} / \mathrm{L})$ whereas minimum concentration was observed in $\mathrm{W}_{4}(0.0109 \mathrm{mg} / \mathrm{L})$. The level of Fe was detected highest in sample $W_{7}(1.787 \mathrm{mg} / \mathrm{L})$ and lowest in $\mathrm{W}_{12}(0.2176 \mathrm{mg} / \mathrm{L})$.

Kumar et al. (2013) [12] studied on the heavy metal content in sea water and showed that the $\mathrm{Cu}$ ranged from 45.29 to $51.02 \mathrm{mg} / \mathrm{L}, \mathrm{Cr} 11.60$ to $15.75 \mathrm{mg} / \mathrm{L}, \mathrm{Ni} 12.01$ to 15.69 $\mathrm{mg} / \mathrm{L}$ and $\mathrm{Pb} 4.10$ to $6.20 \mathrm{mg} / \mathrm{L}$. Ambedkar and Muniyan (2012) [11] analyzed $\mathrm{Cr}, \mathrm{Cu}, \mathrm{Pb}$ and Fe content in water. They found $0.70 \pm 0.026 \mathrm{mg} / \mathrm{L} \mathrm{Cr}, 0.50 \pm 0.025 \mathrm{mg} / \mathrm{L} \mathrm{Cu}, 0.46 \pm$ $0.018 \mathrm{mg} / \mathrm{L} \mathrm{Pb}$ and $0.32 \pm 0.015 \mathrm{mg} / \mathrm{L} \mathrm{Fe}$ in water. The analysis detected that all water samples were lower $\mathrm{Cu}, \mathrm{Cr}, \mathrm{Ni}$ and $\mathrm{Pb}$ content than the range reported by Kumar et al. (2013) [12] and Ambedkar and Muniyan (2012) [11] but higher Fe content was found than Ambedkar and Muniyan (2012) [11]. Accumulation of heavy metals in the aquatic environments have been associated with urban runoff, sewage treatment plants, industrial effluents and wastes, mining operations, boating activities, domestic garbage dumps and agricultural fungicide runoff [13]. 


\section{Heavy metal in sea fish}

The Mean concentrations and associated standard deviations of $\mathrm{Cr}, \mathrm{Cu}, \mathrm{Ni}, \mathrm{Pb}$ and $\mathrm{Fe}$ in sea fish (pama croaker, bombay duck and rat-tail anchovy) are presented in Table 4. The mean concentration of heavy metals were found in all fish samples in the range as $\mathrm{Cr}$ $3.2039-16.3495 \mathrm{mg} / \mathrm{Kg}$ dry wt., $\mathrm{Cu} 1.5589-4.5848 \mathrm{mg} / \mathrm{Kg}$ dry wt., Ni $0.1101-1.9029$ $\mathrm{mg} / \mathrm{Kg}$ dry wt., $\mathrm{Pb} 0.4373-2.7638 \mathrm{mg} / \mathrm{Kg}$ dry wt. and Fe $30.9599-108.780 \mathrm{mg} / \mathrm{Kg}$ dry wt. The distribution of heavy metals in fish samples analyzed were in the order of magnitude as $\mathrm{Fe}>\mathrm{Cr}>\mathrm{Cu}>\mathrm{Pb}>\mathrm{Ni}$. Jezierska and Witeska (2006) [14] detected heavy metals in live fish usually follow the ranking: $\mathrm{Fe}>\mathrm{Pb}>\mathrm{Cu}>\mathrm{Cd}>\mathrm{Hg}$. According to Ambedkar and Muniyan (2012) [11], the contents of heavy metals in the all fish organs analyzed were in the order of $\mathrm{Cr}>\mathrm{Cu}>\mathrm{Pb}>\mathrm{Fe}$. The analysis showed that magnitudes of heavy metal were more or less similar with Jezierska and Witeska (2006) [14] reported but differ from Ambedkar and Muniyan (2012) [11]. The variation might be due to metal accumulation in fish and various fish species living in the same water body with different level of contamination in water.

\section{Concentration of heavy metal in sea water fish*}

Table 4

\begin{tabular}{|c|c|c|c|c|c|}
\hline $\begin{array}{c}\text { Fish } \\
\begin{array}{c}\text { Sample } \\
\text { Code }\end{array}\end{array}$ & $\begin{array}{c}\text { Cr (mg/Kg } \\
\text { dry wt.) }\end{array}$ & $\begin{array}{c}\text { Cu (mg/Kg } \\
\text { dry wt.) }\end{array}$ & $\begin{array}{c}\text { Ni (mg/Kg } \\
\text { dry wt.) }\end{array}$ & $\begin{array}{c}\text { Pb (mg/Kg } \\
\text { dry wt.) }\end{array}$ & $\begin{array}{c}\text { Fe (mg/Kg } \\
\text { dry wt.) }\end{array}$ \\
\hline $\mathrm{P}_{1}$ & $5.8931 \pm 0.4799$ & $2.9826 \pm 0.0519$ & $1.2259 \pm 0.0201$ & $1.5247 \pm 0.1430$ & $34.3399 \pm 0.7788$ \\
\hline $\mathrm{P}_{2}$ & $3.6049 \pm 0.0702$ & $4.0512 \pm 0.0246$ & $1.1303 \pm 0.0509$ & $1.7494 \pm 0.1561$ & $78.4812 \pm 0.6901$ \\
\hline $\mathrm{P}_{3}$ & $5.7798 \pm 0.6082$ & $2.8343 \pm 0.0615$ & $1.0733 \pm 0.0423$ & $1.5914 \pm 0.2352$ & $30.9599 \pm 0.6071$ \\
\hline $\mathrm{P}_{4}$ & $3.5654 \pm 0.4884$ & $4.0548 \pm 0.0246$ & $1.1680 \pm 0.0588$ & $1.6669 \pm 0.1727$ & $79.2792 \pm 0.1692$ \\
\hline $\mathrm{B}_{1}$ & $3.2039 \pm 0.2504$ & $2.8581 \pm 0.0246$ & $1.9029 \pm 0.0217$ & $1.9964 \pm 0.0859$ & $39.0306 \pm 0.7464$ \\
\hline $\mathrm{B}_{2}$ & $4.1452 \pm 0.4207$ & $2.1553 \pm 0.0292$ & $0.8601 \pm 0.0469$ & $0.5675 \pm 0.0489$ & $34.9958 \pm 0.2801$ \\
\hline $\mathrm{B}_{3}$ & $3.2842 \pm 0.3392$ & $2.6436 \pm 0.0292$ & $1.7545 \pm 0.0491$ & $1.5193 \pm 0.2173$ & $37.5378 \pm 0.2475$ \\
\hline $\mathrm{B}_{4}$ & $4.3846 \pm 0.4186$ & $2.1408 \pm 0.0604$ & $0.7716 \pm 0.0073$ & $0.4373 \pm 0.1759$ & $35.079 \pm 0.2426$ \\
\hline $\mathrm{R}_{1}$ & $16.3495 \pm 0.480$ & $4.5848 \pm 0.3676$ & $0.9126 \pm 0.1773$ & $2.7638 \pm 0.3460$ & $108.780 \pm 1.778$ \\
\hline $\mathrm{R}_{2}$ & $9.7973 \pm 0.3718$ & $1.6085 \pm 0.1129$ & $0.1101 \pm 0.0915$ & $\mathrm{BDL}$ & $91.913 \pm 4.043$ \\
\hline $\mathrm{R}_{3}$ & $16.1246 \pm 0.584$ & $4.1436 \pm 0.1514$ & $0.5969 \pm 0.1071$ & $2.5346 \pm 0.8953$ & $106.618 \pm 1.289$ \\
\hline $\mathrm{R}_{4}$ & $8.1584 \pm 0.3056$ & $1.5589 \pm 0.3856$ & $0.1459 \pm 0.1077$ & $\mathrm{BDL}$ & $92.822 \pm 0.914$ \\
\hline
\end{tabular}

* Values are mean \pm standard deviation of triplet determinations; BDL=Below Detection Level

The highest concentration level of $\mathrm{Cr}$ was found in $\mathrm{P}_{1}\left(5.8931 \mathrm{mg} / \mathrm{Kg}\right.$ dry wt.), $\mathrm{B}_{4}$ (4.3846 mg/Kg dry wt.) and $\mathrm{R}_{1}(16.3495 \mathrm{mg} / \mathrm{Kg}$ dry wt.) in pama croaker, bombay duck and rat-tail anchovy respectively. Contamination levels of heavy metal in fish are normally compared to the permissible limits recommended by Food and Agriculture Organization (FAO) and World Health Organization (WHO) [15]. In this research, 17\% fish samples had excess amount of $\mathrm{Cr}$ among all samples whereas acceptable limit is $15.0 \mathrm{mg} / \mathrm{kg}$ for fish according to $[15,16]$. Furthermore, chromium is also more harmful in its lower oxidation state (III). Chromium and chromates are potential carcinogens [17]. 
The maximum concentration of $\mathrm{Cu}$ was observed in $\mathrm{P}_{4}\left(4.0548 \mathrm{mg} / \mathrm{Kg}\right.$ dry wt.), $\mathrm{B}_{1}$ ( $2.8581 \mathrm{mg} / \mathrm{Kg}$ dry wt.) and $\mathrm{R}_{1}(4.5848 \mathrm{mg} / \mathrm{Kg}$ dry wt.) in pama croaker, bombay duck and rat-tail anchovy respectively. Mean concentration of $\mathrm{Cu}$ in fish samples was lower compared with FAO/WHO (1984) [15] permissible level (20 mg/Kg). Though copper is an essential element that serves as a cofactor in a number of enzymes systems and necessary for the synthesis of hemoglobin, very high intake of $\mathrm{Cu}$ can cause adverse health problems for most living organism [18].

The level of Ni was detected highest in sample $\mathrm{P}_{4}\left(1.1680 \mathrm{mg} / \mathrm{Kg}\right.$ dry wt.), $\mathrm{B}_{1}(1.9029$ $\mathrm{mg} / \mathrm{Kg}$ dry wt.) and $\mathrm{R}_{3}\left(0.5969 \mathrm{mg} / \mathrm{Kg}\right.$ dry wt.) and lowest in $\mathrm{P}_{3}\left(1.0733 \mathrm{mg} / \mathrm{Kg}\right.$ dry wt), $\mathrm{B}_{4}$ $\left(0.7716 \mathrm{mg} / \mathrm{Kg}\right.$ dry wt.) and $\mathrm{R}_{2}(0.1101 \mathrm{mg} / \mathrm{Kg}$ dry wt.) in pama croaker, bombay duck and rat-tail anchovy respectively. According to the FAO/WHO (1984) [15] maximum permissible concentration is $80 \mathrm{mg} / \mathrm{Kg}$ for $\mathrm{Ni}$ in fish muscle. In this study, Ni concentration for all studied fish species was lower than $\mathrm{FAO} / \mathrm{WHO}$ standard [15].

$\mathrm{Pb}$ content in $\mathrm{P}_{2}\left(1.7494 \mathrm{mg} / \mathrm{Kg}\right.$ dry wt.), $\mathrm{B}_{1}\left(1.9964 \mathrm{mg} / \mathrm{Kg}\right.$ dry wt.) and $\mathrm{R}_{3}(2.5346$ $\mathrm{mg} / \mathrm{Kg}$ dry wt.) were higher in pama croaker, bombay duck and rat-tail anchovy respectively. It was found that mean concentrations of $\mathrm{Pb}$ in all fish samples were $17 \%$ below detection level (BDL), 17\% below, 33\% optimum and 33\% higher than the maximum permitted concentrations $(1.5 \mathrm{mg} / \mathrm{Kg})$ recommended by FAO/WHO [15]. Lead toxicity is known to cause musculo-skeletal, renal, ocular, neurological, immunological, reproductive and developmental effects [11].

The highest Fe content was found in sample $\mathrm{P}_{4}\left(79.2792 \mathrm{mg} / \mathrm{Kg}\right.$ dry wt.), sample $\mathrm{B}_{1}$ (39.0306 mg/Kg dry wt.) and Sample $R_{1}(108.780 \mathrm{mg} / \mathrm{Kg}$ dry wt.) while the lowest value was found $30.9599 \mathrm{mg} / \mathrm{Kg}$ dry wt. in sample $\mathrm{P}_{3}, 34.9958 \mathrm{mg} / \mathrm{Kg}$ dry wt. in sample $\mathrm{B}_{2}$ and $91.913 \mathrm{mg} / \mathrm{Kg}$ dry wt. in sample $\mathrm{R}_{2}$ for pama croaker, bombay duck and rat-tail anchovy respectively. It was found that mean concentrations of $\mathrm{Fe}$ in all fish samples were $33 \%$ below, $17 \%$ optimum and 50\% higher than the maximum permitted concentrations (43 $\mathrm{mg} / \mathrm{Kg}$ ) recommended by $\mathrm{FAO} / \mathrm{WHO}$ [15]. Excess amount of iron causes rapid increase in pulse rate and coagulation of blood in blood vessels, hypertension and drowsiness [17].

The presence of heavy metal in the fish sample might be due to untreated industrial discharges, sewage effluents, illegal waste dumping activity, nearby chemical fertilizer industries, domestic wastes and some anthropogenic activities.

\section{Conclusion}

Metal has a variety of unpleasant effects, which can impact individual health and produce different harmful changes in human. Knowledge of heavy metal concentrations in sea water and marine fishes are important in order to regulate the consumption of fish. The distribution of heavy metals in water samples analyzed were in the order of magnitude as $\mathrm{Fe}>\mathrm{Ni}>\mathrm{Pb}>\mathrm{Cr}>\mathrm{Cu}$. On the other hand, among the metals analyzed in fish muscle, $\mathrm{Cr}$, $\mathrm{Pb}$ and $\mathrm{Fe}$ were with the highest concentration, while $\mathrm{Cu}$ and $\mathrm{Ni}$ had the lowest level according to FAO/WHO (1984) [15]. Though the results reveal some higher heavy metal content in fish, it is important to examine the metal concentration in fish through constant monitoring. The metal contaminants perhaps pose little hazard to human for fish consumption. Therefore, future studies should focus on health risks posed by metal contamination in the other biological factor along with seasonal variations. 


\section{References}

1. Chan H. M., Trifonopoulos M., Ing A., Receveur O., Johnson E. (1999), Consumption of freshwater fish in Kahnawake: risks and benefits, Environmental Research, 80(2), pp. 213222.

2. Darwish A.M., El- Mossalami M.K., El- Bassiony R.A. (2003), Quality assurance of some fatty fishes, Assuit Veterinary Medical Journal, 49 (98), pp. 79-96.

3. El-Kattan, Y.A., Nahla, A. Abo-El Roos. (2008), Levels of some heavy metals in River Nile water and Oreochromis niloticus fish at Menoufia Governorate, Egyptian Journal of Comparative Pathology \& Clinical Pathology, 21(1), pp. 64-75.

4. WHO, (1999), Food safety issues associated with products from aquaculture, Report of a Joint FAO/NACA/WHO Study Group, World Health Organization Technical Report Series 883 , pp. $1-55$.

5. Jarup L. (2003), Hazards of heavy metal contamination, British Medical Journal, 68, pp. 167-182.

6. Saeed S. M., Shaker I. M., (2008), Assessment of heavy metals pollution in water and sediments and their effect on Oreochromis niloticus in the northern delta lakes, Egypt, 8th International Symposium on Tilapia in Aquaculture, pp. 475.

7. Santos, I. R., Silva-Filho E. V., Schaefer C. E., Albuquerque- Filho M. R., Campos. L. S. (2005), Heavy metals contamination in coastal sediments and soils near the Brazilian Antarctic Station, King George Island, Marine Pollution Bulletin, 50, pp. 85-194.

8. A.P.H.A. (American Public Health Association) (1985), Standard methods for examination of water and waste water, 16th Ed. Washington, D.C.

9. Jorhem, L., (1993), Determination of metals in foodstuffs by atomic absorption spectrometry after dry ashing: NMKL interlaboratory study of $\mathrm{Pb}, \mathrm{Cd}, \mathrm{Zn}, \mathrm{Cu}, \mathrm{Fe}, \mathrm{CR}$ and $\mathrm{Ni}$, Journal of AOAC international, 76, pp. 798-815.

10. Ismail I., Saleh M. I., (2012), Analysis Of Heavy Metals In Water And Fish (Tilapia Sp.) Samples From Tasik Mutiara, Puchong, The Malaysian Journal of Analytical Sciences, 16 (3), pp. 346-352.

11. Ambedkar G., Muniyan M. (2012), Analysis of heavy metals in water, sediments and selected freshwater fish collected from gadilam river, tamilnadu, india, International Journal of Toxicology and Applied Pharmacology, 2(2), pp. 25-30.

12. Kumar C.S., Jaikumar M., Robin R.S., Karthikeyan P., Kumar C.S., (2013), Heavy Metal Concentration of Sea Water and Marine Organisms in Ennore Creek, Southeast Coast of India, The Journal of Toxicology and Health, 103, pp. 192-201.

13. Alemdaroglu T., Onur E., Erkakan F. (2003), Trace metal levels in surface sediments of lake Manyas, Turkey and Tributary River, International Journal of Environmental Studies, 60, pp. 287-298.

14. Jezierska B., Witeska, M. (2006), The metal uptake and accumulation in fish living in polluted waters; Soil and Water Pollution Monitoring, Protection and Remediation Springer, pp. 3-23.

15. FAO/WHO (1984), List of maximum levels recommended for contaminants by the Joint FAO/WHO Codex Alimentarius Commission. Second Series CAC/FAL, Rome, pp. 1-8.

16. FEPA (Federal Environmental Protection Agency) (2003), Guidelines and standards for Environmental Pollution Control in Nigeria, pp. 238.

17. Patil G., Ahmed I., (2011), Heavy metals contamination assesment of kanhargaon dam water near chhindwara city, Acta Chimica and Pharmaceutica Indica, 1(1), pp. 7-9.

18. Sivaperumal P, Sankar T V, Nair Viswanathan P.G. (2007), Heavy metals concentrations in fish, shellfish and fish products from internal markets of India visàvis international standards, Food Chemistry, 102, pp. 612-620. 